(C) The Author(s), 2021. Published by Cambridge University Press on behalf of the Arizona Board of Regents on behalf of the University of Arizona. This is an Open Access article, distributed under the terms of the Creative Commons Attribution licence (http://creativecommons.org/licenses/by/4.0/), which permits unrestricted re-use, distribution, and reproduction in any medium, provided the original work is properly cited.

\title{
WALLY, MENTOR OF THE YOUNG
}

\section{Thomas F Stocker(10}

Climate and Environmental Physics, Physics Institute, Oeschger Centre for Climate Change Research, University of Bern, Switzerland

Wally Broecker shaped an entire era of Earth System science with his unsurpassed overview both in time and space. His creativity seemed endless, his scientific breadth, inquisitive depth and innovative power were exceptional. His critical thinking was incisive, sometimes intimidating, but always generous. With his curiosity he has propelled so many young scientists onto a successful path of inquiry and research.

The long road to Wally: The goal of my postdoctoral fellowship at McGill University from 1989 to 1991 was to build a model with which the dynamics of centennial to millennial climate variability could be investigated. The project that I submitted to the Swiss National Science Foundation proposed to close the gap between general circulation models, which are too expensive for such long runs, and statistical dynamical models, which are too simplistic to capture the many feedback mechanisms in the Earth System. I was given trust and money by the Foundation, and Lawrence Mysak, the host at McGill University, provided an inspiring environment for research. It was good fortune that he invited his former $\mathrm{PhD}$ student, the late theoretical oceanographer Daniel Wright, to spend a sabbatical with the group. Coincidentally, the three of us shared in our past a strong interest in shelf wave dynamics, rather removed from climate!

My goal to build a coupled atmosphere-ocean climate model of intermediate complexity, as we called it, the brilliant mathematical skills of Dan, and the continuous and enthusiastic support by Lawrence were the perfect combination to construct a zonally averaged three-basin ocean model. It was coupled to an atmospheric energy balance model, to form a "2.5-dimensional" climate model that enabled multi-millennial simulations on a personal computer (Stocker et al. 1992b; Wright and Stocker 1991). Seeking relevant applications for our model, and having just recently heard about the Great Conveyor Belt of a certain Professor Wallace Broecker at Columbia University (Broecker 1987a), I wrote a letter to Professor Broecker in 1990 presenting our climate model and hoping to establish a contact. My plan failed miserably: I got no response.

In that same year, Hans Oeschger of the University of Bern, then the only climate scientist in Switzerland and an outspoken researcher who had warned early that the relentless rise in the atmospheric $\mathrm{CO}_{2}$ concentration could disturb the radiation balance in a dangerous way (Siegenthaler and Oeschger 1978), organized a climate change conference in Switzerland. CLIMA Locarno 90 promised to be the event to participate, as on the program the eminent climate scientists Wolf Berger from Scripps Institution of Oceanography and Wally Broecker from Columbia University were announced to debate what Younger Dryas really

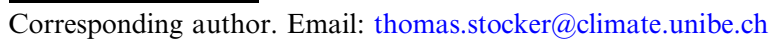



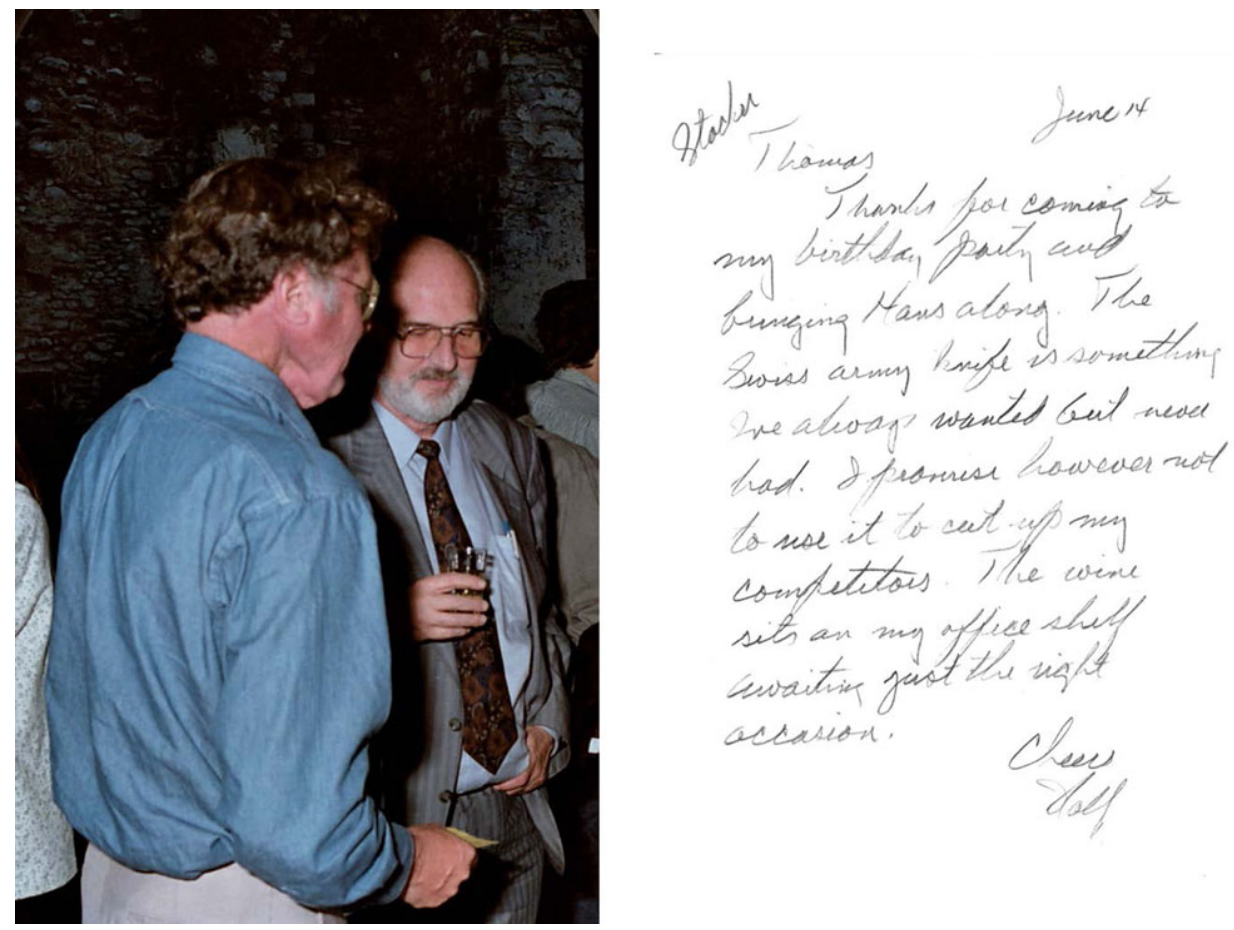

Figure 1 Two documents illustrating the crossing of paths of two giants of paleoclimate science, Wally Broecker and Hans Oeschger. Left: At the reception in Locarno (Switzerland, 25 Sept. 1990). Right: a Wally-type letter acknowledging the visit of Hans to his birthday party at the occasion of Hans's return home from the award ceremony of the Tyler Prize for Environmental Achievement, which Hans received in 1996.

was. This pronounced millennial cold snap that interrupted the warming from the last ice age to the Holocene was identified in pollen and isotope profiles in Swiss lakes (Eicher and Siegenthaler 1976) as well as in the Camp Century ice core of Greenland (Dansgaard et al. 1969). It became an icon of abrupt climate change (Oeschger et al. 1984), whose global significance Wally recognized instantly (Broecker et al. 1985). Therefore, the debate in Locarno promised to be heated, and so it was. As a young postdoc I could only admire the enthusiasm, the passion, and the knowledge of these two giants on the podium. Arguments, claims and counterclaims were hurled back and forth. Almost every statement generated a question that could be addressed by our simplified climate model. Therefore, I was most excited to meet Wally in person at that conference.

Walking to the conference dinner with Hans and Wally (Figure 1), Wally asked me what I was up to, and I responded that I was scheduled to return to Switzerland after my postdoc in Canada. "Do you want to come to Lamont?" I still hear him asking, which felt to a young scientist like a Royal Flush in a poker game. This appeared much more exciting than returning to Switzerland! To work at Lamont, that famous Lamont-Doherty Geological Observatory, where so many iconic insights about the Earth System were produced, and to become a postdoc of Professor Broecker was most attractive! I did not know that he was on the lookout for a climate modeler who would not slow him down by saying that the 
requested simulations were too complicated or too costly, or that the tracer of interest had a lifetime that was too long for representing it in a dynamic model. The model of intermediate complexity would come in just handy for Wally, as did the person who did not mind a relocation from Montreal to New York after the completion of the fellowship there.

Of course, it was not that easy: a few months later Wally sent me a short mail instructing me to write a research proposal that he would submit to the US Department of Energy-he knew he would get the money, and so it was! Before long, I sat in the Geochemistry Building at Lamont, Tracers in the Sea on my desk, ploughing through the homework given to me by Wally, and occasionally summoned into his office to respond to questions such as: "What happens if you hit your model with ...?" or "What is radiocarbon doing in the atmosphere when the conveyor collapses?" Wally was very keen to learn about the consequences when the "angry beast is poked with sticks," how the conveyor belt would react to flushes of freshwater discharged at different locations, to anthropogenic heating, or the changes of wind systems steering the atmospheric moisture fluxes.

In the stimulating environment of Wally, the Lamont community and the frequent visitors, we addressed the question whether changes in high-latitude forcing would have a global effect. With the conveyor belt in mind and a dynamical model at hand, we could investigate the north-south connection mediated by the ocean's deep circulation. Higher salinities around Antarctica would shift water masses such that Antarctic Bottom Water (AABW) would become dominant in the deep ocean, whereas more saline surface waters in the North Atlantic would push AABW back to the Southern Ocean (Stocker et al. 1992a). The close connection to Tom Crowley's work is evident (Crowley 1992), but unknown to either of us at the time. In the 1992 paper Tom Crowley called this connection "North and South Atlantic seesaw," and it was Wally five years later who coined it crisply "bipolar seesaw" (Broecker 1997a), a term that has since become commonplace in paleoclimate research of the late Pleistocene.

In the meantime, there were conflicting signals from the paleoclimatic archives whether or not abrupt climate change of the type of the rapid cold-warm switches in Greenland during the ice age (Dansgaard et al. 1993), or the end of the Younger Dryas, were synchronous global events (Denton and Hendy 1994), and thus the seesaw was just a climate model peculiarity. Wally himself was seesawing between global phasing and north-south antiphasing, and he considered this one of the top two scientific questions in paleoclimate research to be resolved (Broecker 1997a). By then his favorite was clear (Broecker 1998), but it was not model simulations that convinced him (Stocker and Wright 1996), none of which showed a global cooling upon the collapse of the conveyor belt in the North Atlantic (Mikolajewicz et al. 1997; Mikolajewicz and Maier-Reimer 1994). Rather, it was new paleoclimatic evidence (Blunier et al. 1998; Singer et al. 1998) that consolidated Wally's position. The high-resolution ice core results from Taylor Dome, published only a few months later, seemed to stab the bipolar seesaw in the back again (Steig et al. 1998). This paper triggered an interesting discussion (Cane 1998; Stocker 1998), but later it turned out that the ice core section so close to bedrock contained a hiatus, destroying the integrity of the time scale.

It seems that the question of north-south antiphasing confused many, because it was obvious that the Antarctic isotope signals were not nearly as abrupt as those from Greenland. At one of his legendary visits to Bern, Sigfùs Johnsen from the University of Copenhagen told me over a coffee: "The Antarctic isotope records look like the integral of the Greenland record, but I 
don't know why." I suspected that the integrator was the heat reservoir of the Southern Ocean and so the "thermal bipolar seesaw" was born (Stocker and Johnsen 2003). Before long, this was impressively confirmed by the high-resolution ice core from Dronning Maud Land (EPICA Community Members 2006). Although the simplicity of this concept is intriguing and a useful zero-order description, it turns out that Nature is somewhat more complicated (Pedro et al. 2018).

During my stay with Wally at Lamont I learned another important element of scientific work: communication of climate science to policymakers. Already in 1975, Wally had warned about the danger of global warming induced by carbon dioxide (Broecker 1975). Based on the knowledge of the abrupt conveyor switches in the past, Wally worried that this could also happen in the future (Broecker 1987b). This, together with the emerging results from the two Greenland ice cores of the European GRIP and the US GISP2 projects (Dansgaard et al. 1993; Taylor et al. 1993), has focused the world's attention on abrupt climate change as a response to anthropogenic activity.

One of the very rare science-minded politicians got interested. Al Gore, then Senator of Tennessee, visited Wally several times at Lamont to be briefed about the latest information on the Great Conveyor belt. The senator tapped the vast knowledge of Wally and the Lamont colleagues on the Earth System and its response to anthropogenic interference in preparation for his book written for the wider public (Gore 1992). Wally saw it as his responsibility as a scientist not only to understand the Earth System but also to inform the public and policymakers about the serious consequences of burning fossil fuels. Around the same time, Al Gore convened a series of congressional hearings on "Global Change Research, Global Warming, and the Oceans" and invited Wally to testify. Wally passed on the baton to me, and so the administration in Washington was challenged to find out whether this foreign young postdoc could be permitted to enter the halls of Congress and would be capable to testify. After a lengthy telephone interview, an invitation was extended for the briefing (Figure 2). It was certainly a steep lesson for me to be thrown into cold water and talk about science in such an unfamiliar and formal setting. I still keep the verbal minutes of this meeting in my files.

This assignment has triggered me to use the climate model of intermediate complexity to investigate the consequences of "poking the angry beast." It was known that the conveyor would weaken under moderate warming and even collapse under strong warming, as shown in an inspiring study by Suki Manabe and Ron Stouffer (Manabe and Stouffer 1993). It turned out that the speed of "poking" was also important. We were surprised to find that a slower increase to a certain level of atmospheric $\mathrm{CO}_{2}$ concentration showed a fundamentally different response by the conveyor than a faster increase to the same level. In the former case, the conveyor recovered, in the latter the ocean circulation collapsed for good (Stocker and Schmittner 1997). It was clearly Wally who planted the seed of this research many years before, and it was very gratifying for me to see that Wally found that work useful (Broecker 1997b; Broecker 2012).

During my time at Lamont from 1991 to 1993, the search for Hans Oeschger's successor at the University of Bern was going on. I suspect that Wally had a hand in this, and when asked informally by Hans about possible candidates, Wally suggested two names. When the first candidate turned the offer down, I stopped by Wally's office for advice. Without any hesitation he persuaded me to take the job in Bern. A typically bold Wally action. His 


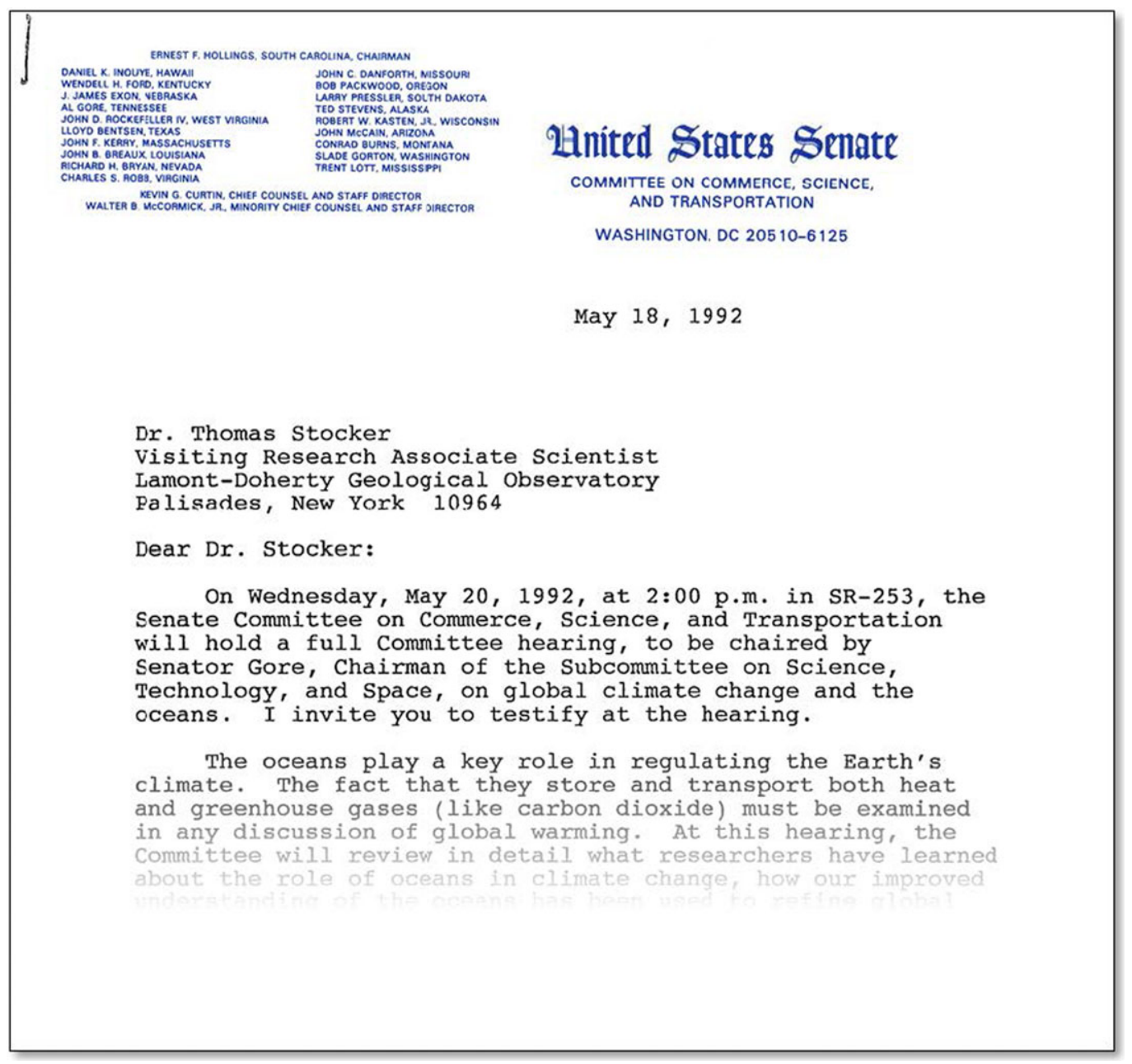

Figure 2 Invitation letter from Washington, DC to testify on the role of the ocean in global climate change.

faith and conviction in young scientists, his encouragement and mentoring were exceptional. Wally has groomed a legion of young scientists by deeply trusting them, while at the same time tacitly conveying the expectation not to disappoint.

In the early 1990s, Bern had already contributed in leading positions to the First and Second Assessment Reports of the Intergovernmental Panel on Climate Change (IPCC), with Hans Oeschger, Uli Siegenthaler, and Fortunat Joos as lead authors in those reports. It was natural for me to also engage in IPCC. Leading chapters in the Third and Fourth Assessment Report was an excellent school of consensus-finding work with colleagues around the world and produced a document that provided a scientific basis for the policy process. It is quite a unique experience to translate very technical results from the science into a document that is eventually approved by 195 countries. Wally did not hide his skepticism towards the IPCC assessment process and my involvement which occupied a good part of my time and which reduced the research output. But from a distance he was generously observing my office as co-chair of IPCC Working Group I for the Fifth 
Assessment Report that started in 2008. After all was done, I visited him in December 2013, and I was so happy to feel and hear his appreciation for this work.

Since then we were in regular contact, receiving his frequent "briefs" which demonstrated his uninterruptable scientific drive. Increasingly it became clear that neither early warnings about the danger of anthropogenic climate change, nor elaborate and voluminous assessment reports produced by the scientists would have any effect for climate change mitigation. Therefore, Wally resuscitated a subject that he has contemplated already decades before. In 1984 Wally wrote a manuscript entitled " $\mathrm{SO}_{2}$; A backstop against a bad $\mathrm{CO}_{2}$ trip?" in which he discussed albedo modification. This was proposed earlier but with the opposite goal of making the Arctic habitable (Budyko 1966; Sellers 1969). While the preprint was never published, Wally was convinced that the elimination of fossil fuels was not going to happen soon enough and that some form of geoengineering was necessary to avoid dangerous climate change. One can imagine that we engaged in serious discussions, as I personally believe that the industrialized man does not show a convincing record of stewardship of our Planet, and so my trust in a successful climate modification experiment is null. Instead, I argue that Article 2 of the United Nations Framework Convention on Climate Change equally applies to the ongoing emissions of $\mathrm{CO}_{2}$ and other greenhouse gases, as it does to ideas about global experiments to reduce global heating. In consequence, elimination of fossil fuels is the only sustainable remedy for the dangerous situation we have maneuvered ourselves into. Wally would have continued to challenge us on this issue, as he did on many issues during his entire scientific career.

I owe a great lot to Wally-he was a motivating, challenging and generous mentor during my 2.5 years at Lamont, and ever since then. In 1993 I moved to Bern, a position that most likely I would not have without him and his famous letters of recommendation and advice to leaders. He believed foremost in the young scientists, and I was among those very fortunate enough to meet him when I was young.

\section{REFERENCES}

Blunier T, Chappellaz J, Schwander J, Dällenbach A, Stauffer B, Stocker TF, Raynaud D, Jouzel J, Clausen HB, Hammer CU et al. 1998. Asynchrony of Antarctic and Greenland climate change during the last glacial period. Nature 394:739-743.

Broecker W. 2012. The carbon cycle and climate change: Memoirs of my 60 years in science. Geochemical Perspectives 2:221-339.

Broecker WS. 1975. Climatic Change: Are we on the brink of a pronounced global warming? Science 189:460-463.

Broecker WS. 1987a. The biggest chill. Natural History 96:74-82.

Broecker WS. 1987b. Unpleasant surprises in the greenhouse? Nature 328:123-126.

Broecker WS. 1997a. Future directions of paleoclimate research. Quaternary Science Reviews 16:821-825.

Broecker WS. 1997b. Thermohaline circulation, the Achilles Heel of our climate system: Will manmade $\mathrm{CO}_{2}$ upset the current balance. Science 278:1582-1588.
Broecker WS. 1998. Paleocean circulation during the last deglaciation: a bipolar seesaw? Paleoceanography 13:119-121.

Broecker WS, Peteet DM, Rind D. 1985. Does the ocean-atmosphere system have more than one stable mode of operation? Nature 315: 21-25.

Budyko MI. 1966. Polar ice and climate. Proc. Symp. Arctic Heat Budget and Atmospheric Circulation. RM-5233-NSF, The RAND Corporation, Santa Monica, CA.: RM-5233-NSF, The RAND Corporation. p. 3-21.

Cane M. 1998. A role for the Tropical Pacific. Science 282:59-61.

Crowley TJ. 1992. North Atlantic deep water cools the southern hemisphere. Paleoceanography 7:489-497.

Dansgaard W, Johnsen SJ, Clausen HB, Dahl-Jensen D, Gundestrup NS, Hammer CU, Hvidberg CS, Steffensen JP, Sveinbjörnsdottir AE, Jouzel J et al. 1993. Evidence for general instability of past climate from a $250-\mathrm{kyr}$ ice-core record. Nature 364:218-220. 
Dansgaard W, Johnsen SJ, Moller J, Langway CC. 1969. One thousand centuries of climatic record from Camp Century on the Greenland ice sheet. Science 166:377-381.

Denton GH, Hendy CH. 1994. Younger Dryas age advance of Franz Josef glacier in the southern alps of New Zealand. Science 264:1434-1437.

Eicher U, Siegenthaler U. 1976. Palynological and oxygen isotope variations on late-glacial sediment cores from Switzerland. Boreas 5: 109-117.

EPICA Community Members. 2006. One-to-one coupling of glacial climate variability in Greenland and Antarctica. Nature 444:195-198.

Gore A. 1992. Earth in the balance. Houghton Mifflin. p. 407.

Manabe S, Stouffer RJ. 1993. Century-scale effects of increased atmospheric $\mathrm{CO}_{2}$ on the oceanatmosphere system. Nature 364:215-218.

Mikolajewicz U, Crowley TJ, Schiller A, Voss R. 1997. Modelling teleconnections between the North Atlantic and North Pacific during the Younger Dryas. Nature 387:384-387.

Mikolajewicz U, Maier-Reimer E. 1994. Mixed boundary conditions in ocean general circulation models and their influence on the stability of the model's conveyor belt. Journal of Geophysical Research 99(C11):22633-22644.

Oeschger H, Beer J, Siegenthaler U, Stauffer B, Dansgaard W, Langway CC. 1984. Late glacial climate history from ice cores. In: Hansen JE, Takahashi $\mathrm{T}$, editors. Climate processes and climate sensitivity. Washington: American Geophysical Union. p. 299-306.

Pedro JB, Jochum M, Buizert C, He F, Barker S, Rasmussen SO. 2018. Beyond the bipolar seesaw: Toward a process understanding of interhemispheric coupling. Quaternary Science Reviews 192:27-46.

Sellers WD. 1969. A global climatic model based on the energy balance of the earth-atmosphere system. Journal of Applied Meteorology 8: 392-400.

Siegenthaler U, Oeschger H. 1978. Predicting future atmospheric carbon dioxide levels. Science 199(4327):388-395.

Singer C, Shulmeister J, McLea B. 1998. Evidence against a significant Younger Dryas cooling event in New Zealand. Science 281:812-814.

Steig EJ, Brook EJ, White JWC, Sucher CM, Bender ML, Lehman SJ, Morse DL, Waddington ED, Clow GD. 1998. Synchronous climate changes in Antarctica and the North Atlantic. Science 282:92-95.

Stocker TF. 1998. The seesaw effect. Science 282: 61-62.

Stocker TF, Johnsen SJ. 2003. A minimum thermodynamic model for the bipolar seesaw. Paleoceanography 18:1087.

Stocker TF, Schmittner A. 1997. Influence of $\mathrm{CO}_{2}$ emission rates on the stability of the thermohaline circulation. Nature 388:862-865.

Stocker TF, Wright DG. 1996. Rapid changes in ocean circulation and atmospheric radiocarbon. Paleoceanography 11:773-796.

Stocker TF, Wright DG, Broecker WS. 1992a. The influence of high-latitude surface forcing on the global thermohaline circulation. Paleoceanography 7:529-541.

Stocker TF, Wright DG, Mysak LA. 1992b. A zonally averaged, coupled ocean-atmosphere model for paleoclimate studies. Journal of Climate 5:773-797.

Taylor KC, Lamorey GW, Doyle GA, Alley RB, Grootes PM, Mayewski PA, White JWC, Barlow LK. 1993. The "flickering switch" of late Pleistocene climate change. Nature 361:432-436.

Wright DG, Stocker TF. 1991. A zonally averaged ocean model for the thermohaline circulation, Part I: Model development and flow dynamics. Journal of Physical Oceanography 21:1713-1724. 